\title{
Making choices-how stochastic decisions determine disease progression
}

\author{
Ki-Sun Park and Karl Pfeifer \\ Eunice Kennedy Shriver National Institute of Child Health and Human Development, Bethesda, Maryland 20814, USA
}

In this issue of Genes $\leftrightarrow$ Development, Ginart and colleagues (pp. 567-578) study a mouse model for Russell-Silver syndrome (RSS) and show that similar cells within one individual can display distinct gene expression patterns because of epigenetic marks that are established stochastically during early development. Their results provide an excellent explanation for phenotypes seen in RSS and other imprinting disorders and especially help us understand how patients with similar or even identical genetic mutations can display distinct disease profiles.

Genomic imprinting is a developmental process (Demars and Gicquel 2012). In all known cases, the imprint is established in germ cells as a localized DNA methylation mark that is specific to either the paternal or maternal chromosome. After fertilization, the DNA methylation mark is maintained even during the large-scale changes in the methylome that are an essential part of early embryonic development. These methylation differences continue to be maintained throughout life in somatic cells, where they result in the parent of origin-specific gene expression that is the hallmark of imprinted genes.

Disruption in the imprinting process at any of these stages can result in loss of allele-specific expression and thus change the dosage of an imprinted gene from $1 \times$ to either $0 \times$ or $2 \times$ depending on the specifics of the locus. In humans, Russell-Silver syndrome (RSS) and BeckwithWiedemann syndrome (BWS) are growth disorders associated with loss of imprinting at genes on chromosome 11p.15. There are multiple genetic lesions that can lead to RSS and BWS, but the majority of cases is associated with epigenetic defects in methylation imprints (Fig. 1; Demars and Gicquel 2012).

BWS is an overgrowth syndrome associated with either gain of methylation at imprinting control region 1 (ICR1) on the maternal chromosome or loss of methylation at ICR2 on the maternal chromosome. RSS is an undergrowth syndrome that is associated primarily with loss of methylation of ICR 1 on the paternal chromosome, lead-

[Keywords: gene expression; imprinting; single cell]

Corresponding author: pfeiferk@mail.nih.gov

Article is online at http://www.genesdev.org/cgi/doi/10.1101/gad.278952. 116. ing to loss of IGF2 expression with concomitant expression of paternal $H 19$.

In previous work, Bartolomei's group (Engel et al. 2004) had established a model for RSS by introducing base pair changes into ICR1. These mutations do not prevent methylation of ICR1 during spermatogenesis. Thus, mutant progeny begin life as zygotes with correctly marked ICR1 methylation imprints. However, the mutations evidently make this mark precarious because examination of tissues in neonates shows that paternal DNA methylation is only partially maintained. Consequently, these tissues show decreased levels of Igf2 and biallelic expression of $H 19$.

Here Ginart et al. (2016) use this same mouse model but apply new RNA FISH technologies to quantify allele-specific expression of H19 and Igf2 in single cells. They show that there are actually two distinct cell populations. Many cells are fully wild type and express only maternal H19 and paternal Igf2. Moreover, these cells have faithfully maintained the paternal-specific DNA methylation mark. However, other cells have lost the paternal-specific methylation at ICR1 and express no Igf2 but equal amounts of paternal and maternal $H 19$.

Most importantly, Ginart et al. (2016) show that these two cell populations are stable and pass on their epigenetic marks and gene expression patterns during cell division. In sum, the net effect of their original DNA mutations is really just to increase the probability that an epigenetic mistake will be made during early embryogenesis. Then, wherever the imprint is lost stochastically, the mistake is faithfully propagated, leading to an individual with patches of epigenetically mutant cells.

Ginart et al. (2016) do not address timing to see when the epigenetic mutations first arise. However, recent studies offer insights into when the epigenome might be most susceptible to alteration. Shipony et al. (2014) compared expression and DNA methylation in pluripotent and somatic cells and found that mechanisms for maintaining epigenetic patterns are distinct in the two cell types. In pluripotent cells, the epigenome is regulated by the

This article is distributed exclusively by Cold Spring Harbor Laboratory Press for the first six months after the full-issue publication date (see http://genesdev.cshlp.org/site/misc/terms.xhtml). After six months, it is available under a Creative Commons License (Attribution-NonCommercial 4.0 International), as described at http://creativecommons.org/ licenses/by-nc/4.0/. 


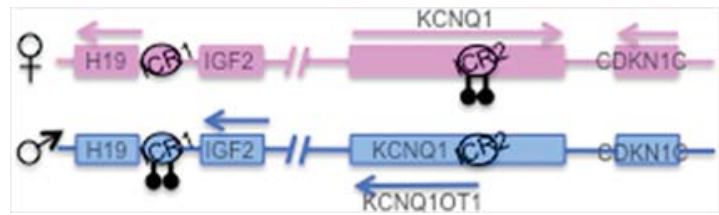

Figure 1. Cartoon depiction of the $11 \mathrm{p} 15$ locus. DNA methylation (filled lollipops) of imprinting control region 1 (ICR1) on the paternal chromosome allows activation of paternal IGF2 by downstream enhancers and also silences the adjacent paternal H19 promoter. On the paternal chromosome, expression of the KCNQ1OT1 antisense transcript prevents expression of KCNQ1 and CDKN1C in cis, while maternal-specific methylation of ICR2 silences the KCNQ1OT1 promoter, thus facilitating KCNQ1 and CDKN1C transcription.

balance of trans factors interacting with regulatory DNA, and the epigenome is relatively amenable to change. In more differentiated cells, the epigenome is regulated mostly by mechanisms designed to faithfully copy the parent cell.

The study by Ginart et al. (2016) has direct implications for understanding the nature of and especially the wide variability in phenotypes in RSS, BWS, and other imprinting disorders. Patients carry mutations that make their imprinting marks vulnerable. Therefore, the stochastic nature of the loss or gain of DNA methylation marks makes every patient unique in regard to the frequency and tissue distribution of epigenetically mutant cells. It is important to note that imprinting disorders are only one extreme case of monoallelic expression. Recent studies suggest that $5 \%-10 \%$ of genes show random monoallelic expression (Savova et al. 2013). Phenotypes associated with these genes might also be unusually sen- sitive to stochastic changes in the epigenome. Finally, the implications of the current study might also extend to individuals carrying alleles that are not monoallelic per se but where alleles are variable in function due to inherited genetic defects. This new study is truly groundbreaking, and it is exciting to see the results of collaboration between classic genetics and new technologies.

\section{Acknowledgments}

This work was supported by the Division of Intramural Research of The Eunice Kennedy Shriver National Institute of Child Health and Human Development.

\section{References}

Demars J, Gicquel C. 2012. Epigenetic and genetic disturbance of the imprinted $11 \mathrm{p} 15$ region in Beckwith-Wiedemann and Silver-Russell syndromes. Clin Genet 81: 350-361.

Engel N, West A, Felsenfeld G, Bartolomei M. 2004. Antagonism between DNA hypermethylation and enhancer-blocking activity at the H19 DMD is uncovered by CpG mutations. Nat Genet 36: 883-888.

Ginart P, Kalish JM, Jiang CL, Yu AC, Bartolomei MS, Raj A. 2016. Visualizing allele-specific expression in single cells reveals epigenetic mosaicism in an H19 loss-ofimprinting mutant. Genes Dev (this issue). doi: 10.1101/ gad.275958.115.

Savova V, Vigneau S, Gimelbrant A. 2013. Autosomal monoallelic expression: genetics of epigenetic diversity. Curr Opin Genet Dev 23: 642-648.

Shipony Z, Mukamel Z, Cohen N, Landan G, Chomsky E, Zeliger SR, Fried YC, Ainbinder E, Friedman N, Tanay A. 2014. Dynamic and static maintenance of epigenetic memory in pluripotent and somatic cells. Nature 513: 115-119. 


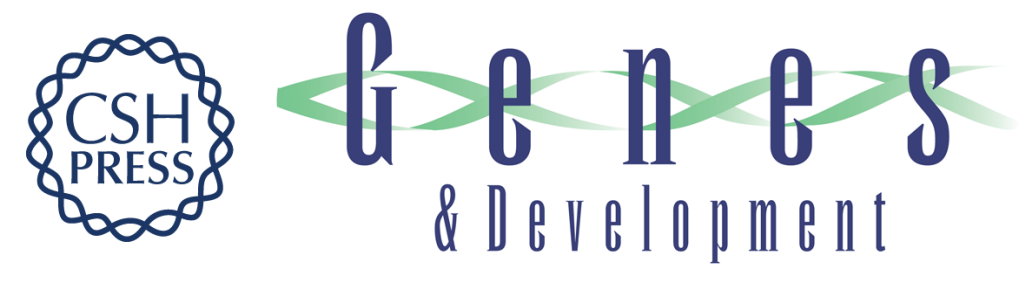

\section{Making choices--how stochastic decisions determine disease progression}

Ki-Sun Park and Karl Pfeifer

Genes Dev. 2016, 30:

Access the most recent version at doi:10.1101/gad.278952.116
Related Content Visualizing allele-specific expression in single cells reveals epigenetic mosaicism in an $\mathrm{H} 19$ loss-of-imprinting mutant
Paul Ginart, Jennifer M. Kalish, Connie L. Jiang, et al.
Genes Dev. March , 2016 30: 567-578
Creative This article is distributed exclusively by Cold Spring Harbor Laboratory Press for the first Commons
License http://genesdev.cshlp.org/site/misc/terms.xhtml). After six months, it is available under a Creative Commons License (Attribution-NonCommercial 4.0 International), as described at http://creativecommons.org/licenses/by-nc/4.0/.
Email Alerting Receive free email alerts when new articles cite this article - sign up in the box at the top Service right corner of the article or click here.

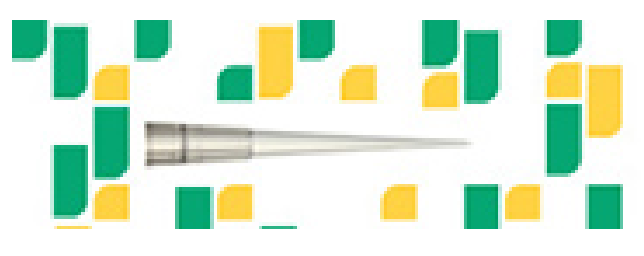

Focused on your science. 